Angela Fleury da Fonseca

\title{
A Interdição em Heráclito e no Budismo
}

Programa de Pós-Graduação em Filosofia Monografia em Filosofia Antiga

Coordenação Central de Extensão / CCE

Departamento de Filosofia

Especialização em Filosofia Antiga

Rio de Janeiro, Julho de 2017 


\section{Pontificia Universidade Católica \\ DO RIO DE JANEIRO}

\section{Angela Fleury da Fonseca}

\section{A Interdição em Heráclito e no Budismo}

Pós-Graduação em Filosofia Monografia de Especialização em Filosofia Antiga

Monografia de Especialização em Filosofia Antiga apresentada como requisito para obtenção do título de Especialista em Filosofia Antiga, Coordenação Central de Extensão - CCE - da Pontifícia Universidade Católica do Rio de Janeiro, PUC-Rio.

Orientadora: Profa. Doutora Lethicia Ouro Oliveira

Rio de Janeiro,

Julho de 2017

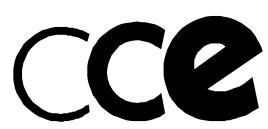

COORDENAÇÃO

CENTRAL DE

EXTENSÃO 


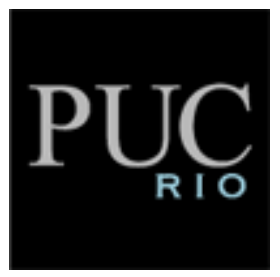

\section{Pontificia Universidade Católica DO RIO DE JANEIRO}

\section{Angela Fleury da Fonseca}

\section{A Interdição em Heráclito e no Budismo}

Monografia apresentada ao Programa de Pós-Graduação em Filosofia como requisito para obtenção do título de Especialista em Filosofia Antiga, Coordenação Central de Extensão / CCE, da Pontifícia Universidade Católica do Rio de Janeiro. Aprovada pela Comissão Examinadora abaixo assinada.

Profa. Doutora Lethicia Ouro Oliveira

Orientadora

Profa. Doutora Lígia Teresa Saramago Pádua

Banca examinadora

Prof. Doutor Ovídio de Abreu Filho

Banca Examinadora

Rio de Janeiro, de de

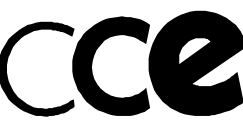


Todos os direitos reservados. É proibida a reprodução total ou parcial do trabalho sem a autorização da universidade, da autora e da orientadora.

\section{Angela Fleury da Fonseca}

Graduou-se em Letras, Licenciatura - Inglês - Português, pela Pontifícia Universidade Católica do Rio de Janeiro, PUC-Rio, em 1975, e lá também, em 1987, cursou a Especialização em Língua Portuguesa (pós-graduação lato sensu). Esteve na Índia nos anos de 1977 e 1978 em busca de conhecimentos da filosofia budista. É tradutora autônoma de livros budistas e professora de língua inglesa. Estudou Budismo Tibetano para o Ocidente de 1997 a 2007 no Instituto Nyingma do Rio de Janeiro. Mestre em Letras, pela Pontifícia Universidade Católica do Rio de Janeiro, PUC-Rio, com a dissertação de Mestrado em Estudos da Tradução "A Tradução das Escrituras Budistas na China: a primeira onda”, em 2009. Cursou a Especialização em Arte e Filosofia, também na Pontifícia Universidade Católica do Rio de Janeiro, PUC-Rio, graduou-se nessa Especialização com a monografia "O horror da condição humana, em seu estado de confinamento e solidão, na pintura de Francis Bacon”, em 2017.

Ficha catalográfica

Fleury da Fonseca, Angela

"A Interdição em Heráclito e no Budismo" / Angela Fleury da Fonseca; orientadora: Lethicia Ouro Oliveira. - 2017. 40p.

Monografia (Especialização) Pontifícia Universidade Católica do Rio de Janeiro, Departamento de Filosofia, Coordenação Central de Extensão, / CCE, Especialização em Filosofia Antiga.

Inclui referências bibliográficas

1. Coordenação Central de Extensão / CCE, Especialização em Filosofia Antiga Monografia. 1. Interdição. 2. Ocultação. 3. Heráclito. 4. Ignorância. 5. Reflexão Abstrativa. 6. Budismo. 7. Bolhas de Realidade. 8. Meditação 9.Natureza da Realidade. I. Ouro Oliveira, Lethicia. II. Pontifícia Universidade Católica do Rio de Janeiro, Departamento de Filosofia, Coordenação Central de Extensão, CCE. 
Para meus filhos Alexandre e Isabela 


\section{Agradecimentos}

À minha querida orientadora Professora Dra. Lethicia Ouro Oliveira, pelas aulas durante a Especialização em Filosofia Antiga, as quais inspiraram o tema desta monografia, à sua pronta aceitação em ser a minha orientadora, a seus valiosos ensinamentos e preciosas sugestões bibliográficas, por ter me incentivado desde o primeiro momento a iniciar esta pesquisa, pela leitura atenta e minuciosa de meu texto, por ter me dado todo o espaço necessário para que eu pudesse trilhar com liberdade os pensamentos heraclítico e budista, pela amizade e pelo carinho.

À Professora Dra. Ligia Teresa Saramago Pádua, pela generosa transmissão de seus preciosos conhecimentos da filosofia de Heidegger, que assim como Heráclito e Buddha, também mergulhou nas profundidades espantosas e nas zonas arriscadas da sabedoria primordial, por sua sensibilidade e espiritualidade e por aceitar participar da banca examinadora.

Ao Professor Dr. Ovídio de Abreu Filho, pelas valiosas aulas durante as especializações em Filosofia Antiga e Arte e Filosofia as quais foram fonte de grande inspiração para minha pesquisa, e por aceitar generosamente em participar da banca examinadora.

Aos meus queridos filhos Alexandre e Isabela por estarem sempre ao meu lado. 


\section{Resumo}

Fonseca, Angela Fleury da; Ouro Oliveira, Lethicia (Orientadora). A Interdição em Heráclito e no Budismo. Rio de Janeiro, 2017. 40p. Programa de Pós-Graduação, Especialização em Filosofia Antiga - Coordenação Central de Extensão / CCEDepartamento de Filosofia. Pontifícia Universidade Católica do Rio de Janeiro, PUCRio.

O objetivo dessa monografia - "A Interdição em Heráclito e no Budismo" - é fazer um breve estudo comparativo entre as reflexões do filósofo pré-socrático Heráclito e da filosofia Budista a respeito da possibilidade humana de compreender a verdadeira natureza da realidade. O presente estudo se debruça mais especificamente sobre a noção de interdição/ocultação que em uma primeira e mais tradicional leitura parece ter sido esquecida pela metafísica socrático- platônica, e mapear os fragmentos de Heráclito e os ensinamentos de Buddha, na procura por pontos em comum que possam nos dar alguma pista de que os dois mestres estavam falando de um saber que possa ter alguma ligação entre si.

\section{Palavras - chave}

Interdição; Ocultação; Heráclito; Reflexão Abstrativa; Budismo; Bolhas de Realidade; Meditação; Natureza da Realidade. 


\section{Sumário}

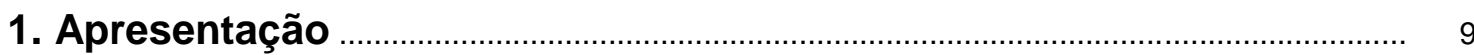

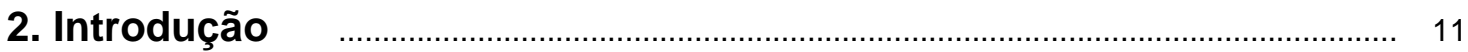

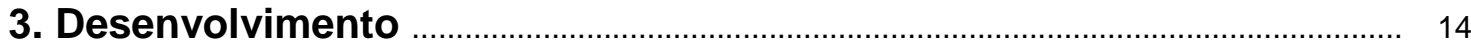

3.1 A Metafísica Clássica platônica e o esquecimento da Interdição .................. 14

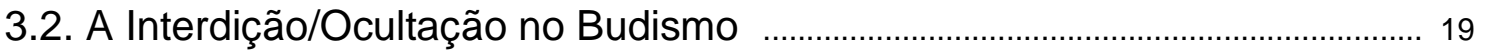

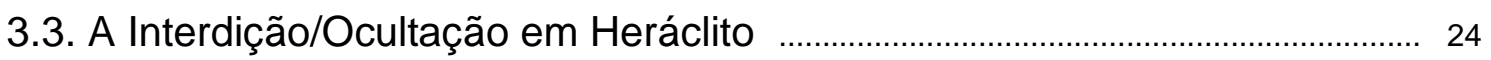

3.4. Semelhanças entre as visões de Buddha e de Heráclito $\quad$............................... $\quad 27$

3.5. Visões Metafísicas como apenas apreensões parciais da realidade $\quad$.......... 31

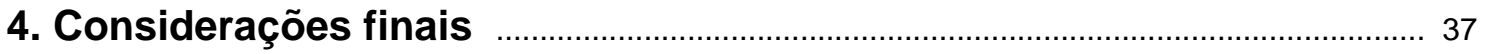

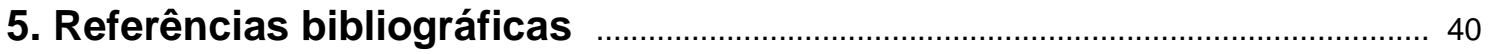


A realidade abrange tudo: a natureza absoluta é uma só. Embora possamos sentir que somos separados de uma realidade original incriada - que a chamemos de "Deus", ou "experiência suprema", ou "mente iluminada" - sabemos que por meio da consciência podemos entrar em contato com essa parte essencial de nós mesmos. (Tarthang Tulku, 2007)

O pensamento abstrato de Heráclito é uma descida a profundidades espantosas. É um avanço audaz para dentro de um mundo de incógnitos, acesso intrépido a zonas arriscadas. Quem o seguisse, havia de estar alerta, vigilante e disposto a enfrentar toda espécie de incompreensões e resistências. Ora, o homem medíocre detesta o estado de prontidão. Recusa a marcha para dentro do ignoto. Prefere o distanciamento de riscos e imprevistos. Adora a euforia esquecida de problemas cruciais. Apraz-se, conforme diz a terceira frase do fragmento 1 , do papel do inconsciente que, analogamente a quem dorme, não percebe como está próximo dele, na vida cotidiana, o logos com suas exigências

(Berge, p. 76/77). 


\title{
1. Apresentação
}

\begin{abstract}
Sócrates (469-399), interrogado por Eurípides, sobre qual a sua opinião a respeito dele (Heráclito), teria respondido: "O que dele vim a compreender é magnífico; penso que deve sê-lo também o que não entendi; aliás, é preciso ser alguém mergulhador de Delos para lhe alcançar o sentido"... se os mergulhadores délios eram famosos por descerem até às ultimas profundidades de suas praias, igualmente ilustres seriam os que imergissem no pensar heraclítico: ele, porém, Sócrates, não figuraria entre estes privilegiados (Berge, p.9).
\end{abstract}

Em razão da natureza enigmática do discurso de Heráclito ele se presta a muitas interpretações dificultando assim a recuperação do significado original do texto que chegou até nós. O esforço para recuperar o pensamento autêntico de Heráclito e atingir uma interpretação correta de suas ideias filosóficas talvez seja algo que nunca será bem sucedido. Trazemos cada um de nós, além disso, uma perspectiva particular determinada, o que nos torna capazes de enxergar somente a partir de um determinado ponto o qual delimitamos previamente. Trazemos não somente novos conhecimentos adquiridos em nosso próprio tempo, mas também outras perspectivas de outras interpretações que nos precederam. O que significa dizer que o que podemos fazer é apenas um recorte de uma visão nossa do discurso de Heráclito. (Kahn, p. 107/108). Não vamos esquecer que sua reflexão foi feita em outra época, muito distante da nossa e que foi ouvido por outros ouvintes em outro tempo e em outro lugar e posteriormente interpretada e comentada das mais variadas maneiras. Para conseguirmos ver um significado em suas palavras teremos que articular seu pensamento em nossos próprios termos. Além do mais, como todos os prosadores gregos anteriores a Heródoto e todos os escritos filosóficos até Platão, o texto original de Heráclito está praticamente perdido.

Por outro lado, a leitura do Budismo não é menos complexa. O Budismo não nos apresenta um livro final, uma verdade a ser conhecida e sua perspectiva é bastante incomum dentro da nossa cultura ocidental. O Budismo não nos traz afirmações e uma verdade clara e fixa, está sempre predisposto a averiguar e a ultrapassar as suas próprias formulações, na busca de eliminar o sofrimento humano e atingir o aspecto livre da mente e o despertar de uma nova consciência. Buddha não vem como alguém que vai revelar alguma coisa, o Budismo não se prende a essa ideia de revelação. Quando perguntavam a Buddha o que ele tinha encontrado ao iluminar-se, ele respondia: "Não 
encontrei nada". Não há nada que possa ser formulado, os ensinamentos budistas não podem ser explicados em palavras. Buddha vai ensinar sobre a natureza primordial que não tem formulação.

Além disso, o que denomino Budismo, é preciso que fique claro, não possui uma identidade homogênea, mas refere-se a um multifacetado conjunto de pensamentos que representa uma das mais antigas filosofias do mundo e que ostenta uma história muito rica e ensinamentos infinitamente complexos, os quais foram difundidos, interpretados, comentados e compreendidos através das mais diversas linhagens e culturas. Sabemos que a filosofia budista desde cedo adquiriu a cor local, ou seja, o Budismo sempre se adaptou à cultura de onde chegava, talvez porque Siddartha Gautama, o Buddha da nossa era, lidou basicamente com uma questão universal e, portanto, comum a todos os seres humanos, independente de suas origens: a questão do sofrimento humano. O Budismo sempre se "acomodou" a todas as culturas de chegada. Nos dias de hoje, para se ter uma ideia, temos, além do Budismo Chinês, o Budismo Japonês, o Budismo Tibetano, o Budismo americano, para citar apenas alguns, o que significaria dizer que o Budismo é uma filosofia que vem desde o seu início se transformando e se adaptando às mais diferentes estruturas socioculturais.

Assim sendo, este trabalho será uma perspectiva estritamente particular que pretende circular pelos fragmentos de Heráclito, não em busca de seu pensamento verdadeiro, mas através de uma interpretação que permita paralelamente compará-los, a partir de uma visão por mim delimitada, com alguns ensinamentos budistas que, por sua vez, também não pretendem afirmar nenhuma verdade final. Tenho a clareza de que poderia ter escolhido outros autores, selecionado outros textos e até mesmo seguido vários outros caminhos neste meu passeio pelos pensamentos budista e heraclítico. Ao longo deste percurso tive que, muitas vezes, fazer atalhos, desviar de questões que talvez fossem até muito importantes, evitar detalhes e aprofundamentos talvez essenciais e incluir indicações de semelhanças e contrastes nem sempre previstos desde o início da pesquisa. Em suma, esta monografia caracteriza-se como apenas um dos inúmeros e possíveis olhares para uma possível relação entre apenas alguns complexos ensinamentos de Heráclito e de Buddha. 


\title{
2. Introdução
}

\begin{abstract}
Das coisas invisíveis, assim como das mortais, têm conhecimento certo os deuses; a nós homens, porém, apenas nos é dado fazer conclusões. (Alcmeon, continuando seu fragmento 1, Berge, 1969, p.63).
\end{abstract}

Será sempre muito difícil, como já nos referimos anteriormente, para nós, ocidentais, no século XXI, compreendermos em toda a sua extensão os ensinamentos de Buddha e o pensamento de Heráclito. Assim, é preciso admitir, desde o início, que, em meio a perspectivas tão distintas, o objetivo desta monografia limita-se a empreender um primeiro contacto com a noção de Interdição/Ocultação nos pensamentos budista e heraclítico, reconhecendo desde logo a sua grande complexidade e a sua inevitável simplificação no presente trabalho.

A partir de uma visão e interpretação absolutamente particulares, apesar de sustentadas por uma gama de textos essenciais, de intérpretes e comentadores dos fragmentos de Heráclito, mais especificamente por Damião Berge e Charles H. Kahn e da filosofia budista pela sabedoria do Lama Padma Samten e do Lama Tarthang Tulku, procurarei investigar a noção de Interdição/Ocultação nos ensinamentos de Heráclito e de Buddha. A presente pesquisa visa fazer um breve estudo comparativo entre as profundas reflexões dos dois mestres a respeito da possibilidade humana de compreender a verdadeira natureza da realidade, as quais a partir de um determinado ponto de vista sugerem por um lado, uma oposição ao pensamento platônico, e por outro, ter exercido uma influência nas reflexões de Heidegger.

Este trabalho parte de uma percepção particular de que haveria nas duas filosofias, budista e heraclítica, a crença na existência de algum tipo de interdição, de ocultação, ou seja, da compreensão de que há algo que se reserva e que não se pode inicialmente acessar, um saber dos pré-socráticos de que há essa interdição que pode ser relacionado a um saber budista de que estamos aprisionados em dores e sofrimentos totalmente baseados em pontos fixos artificialmente construídos e condicionados.

O objetivo desta pesquisa será explorar esse saber sobre a Interdição/Ocultação, que em uma primeira e mais tradicional interpretação parece ter sido esquecida pela 
metafísica socrático-platônica, e mapear fragmentos de Heráclito e alguns dos ensinamentos de Buddha, na procura por pontos em comum que possam nos dar alguma pista de que os dois mestres estavam falando de algum saber que talvez possa ter alguma ligação entre si. A noção de aprisionamento budista dentro de bolhas de realidade de dor e sofrimento e a noção heraclítica da ignorância e da inconsciência humana poderiam ser vistas como duas ideias, de alguma maneira, semelhantes? Não tenho a pretensão de responder a essa questão, apenas tenho a intenção de fazer esse recorte e a certeza de que provavelmente estarei levantando ainda mais questionamentos e dúvidas para a nossa já frágil compreensão humana de qual seria a verdadeira natureza da realidade.

Esta monografia compõe-se de cinco capítulos:

No primeiro capítulo, 3.1., "A Metafísica Clássica platônica e o esquecimento da Interdição", procurarei destacar a mudança que ocorreu na passagem da Filosofia Arcaica para a Filosofia Clássica no que se refere à possibilidade de se conhecer. Talvez possamos afirmar que até os pré-socráticos a verdadeira natureza da realidade estava oculta e a inconsciência humana não permitia que se acessasse a "verdade", mas Platão parece ter esquecido essa noção ao defender a esperança de um mundo solar, fora de nós, aberto e visível no qual se vislumbra a possibilidade dos homens caminharem em direção ao "Bem" e assim, deste modo, acessar por completo e definitivamente a verdadeira natureza da realidade.

No segundo capítulo, 3.2., "A Interdição/Ocultação no Budismo” apresentarei as ideias de dois Lamas tibetanos budistas, Lama Padma Samten, do Centro de Estudos Budistas Bodisatva e Lama Tarthang Tulku, do Nyingma Institute, a respeito da perspectiva budista no que se refere à possibilidade humana de alcançar a sabedoria primordial e se livrar da interdição do samsara, ou seja, a possibilidade dos homens de se verem livres da dor e do sofrimento. Procurarei desenvolver, brevemente, a perspectiva budista que nos vê aprisionados, interditados, em uma realidade construída e condicionada às estruturas transitórias e contraditórias.

O terceiro capítulo, 3.3., "A Interdição/Ocultação em Heráclito” consiste basicamente em um recorte nas visões de Berge e Kahn a respeito da noção de 
ocultação para o pré-socrático. Procurarei ressaltar que para Heráclito a presença da ignorância e da mediocridade humanas representa uma grande interdição no caminho para se alcançar o conhecimento da verdadeira natureza da realidade. Há uma ocultação dessa natureza, afirma Heráclito, que está coberta pela presença das aparências empíricas e seu desvelamento requer um árduo esforço pensante e uma nobre elevação moral.

No quarto capítulo, 3.4., "Semelhanças entre as visões de Buddha e de Heráclito", tentarei trazer similaridades entre os dois mestres no que se refere mais especificamente à noção de interdição/ocultação que encontramos no caminho de nossa busca do conhecimento da verdadeira natureza da realidade.

No quinto capítulo, 3.5., "Visões Metafisicas como apenas apreensões parciais da realidade", procurarei ressaltar o debate a respeito do rumo que os estudos do hinduísmo, para Buddha, e da filosofia arcaica, para Heráclito, estavam tomando entre os seus contemporâneos e a percepção, a meu ver semelhante dos dois, de que não se conseguiria ter uma apreensão total da verdadeira natureza da realidade, como parecia estar sendo defendida na época, através de uma experiência empírica e racional.

Finalmente, irei encerrar esta monografia em Filosofia Antiga com algumas considerações gerais e muitos questionamentos levantados a respeito da noção de Interdição em Heráclito e no Budismo. 


\section{Desenvolvimento}

\subsection{A Metafísica Clássica platônica e o esquecimento da Interdição}

Para Heráclito não é através do olho que se chega à verdadeira natureza da realidade. Quem seguisse Heráclito havia de estar disposto a enfrentar toda espécie de incompreensões e resistências. (Berge, p.76/77).

Na Grécia Clássica, com Platão, se promete pela primeira vez um mundo totalmente presente, um mundo solar, no qual o Sol, aquele que produz luz e visibilidade, concede uma verdade. É como se, o Sol, o Bem, guardasse todos os modelos, o modelo da virtude, o da coragem, o da beleza, o da cadeira e assim por diante, todos os modelos das coisas visíveis. Para a metafísica clássica o "Bem” delega a cada uma das Ideias o seu traço específico, sem ocultação, totalmente às claras. Não há nada que se pergunte além do Sol. E o "Bem" está lá, portanto, o quadro está completo. Se há um mundo é porque as Ideias sustentam as coisas no seu ser.

Mas nem sempre se pensou assim.

Antes de Platão, na Grécia Arcaica, filósofos pré-socráticos como Heráclito afirmavam o oposto, que o estar das coisas não podia ser completamente solar, que há algo que se retrai e se oculta. A Physis tende a ocultar-se, afirmava Heráclito no fragmento $123^{1}$. A metafísica clássica grega vem, com Platão, afrouxar essa ocultação e o antigo saber dos pré-socráticos a respeito desta interdição parece, sob esse ponto de vista, ter sido esquecido. Em linhas gerais, Platão parece desconsiderar o pensamento antigo de Heráclito a respeito da tendência da physis de ocultar-se.

Na metafísica clássica, juntamente com essa perspectiva de um mundo solar, há a promessa de que o homem pode conhecer, o Sol brilha e o "Bem", assim como o Sol, se deixa conhecer, se deixa ver pelo olho.

nota ${ }^{1}$ Todas as citações, neste trabalho, dos fragmentos de Heráclito serão baseadas na tradução de BERGE, Damião, 1969. 
Já no primeiro fragmento de Heráclito, ao interpretarmos a primeira frase podemos talvez afirmar certa importância dada ao sentido da audição: Do logos a ser expresso neste livro, e que existe e vale sempre, os homens são sempre ignorantes, quer antes de o terem ouvido, quer apenas tenham começado a percebê-lo. Não temos em Heráclito um mundo solar, uma luz a iluminar um caminho exterior a nós mesmo, que nos levaria na direção do conhecimento.

De acordo com Berge, para a compreensão do logos, segundo Heráclito, não basta ter-se principiado a ouvi-lo. Começar a ouvir é perceber apenas exteriormente. A verdadeira e plena audição é um entendimento, é uma aquiescência interior, que supõe o progresso para além da primeira apreensão exterior (p.65). Para Heráclito o saber estaria oculto dentro de nós, no nosso interior. Para ele, ouvir tem o sentido de "perceber sensivelmente", possuir uma audição plena. Ainda em seu fragmento 1, na segunda frase, Heráclito continua: Pois, embora tudo proceda de acordo com esse logos, eles se parecem com gente sem experiência, cada vez que experimentam falas $e$ atos do gênero que exporei, analisando cada coisa segundo sua physis e interpretandoa como é. Não há uma verdadeira escuta sensível, os seres humanos, preocupados como seus afazeres diários e suas conversas frívolas e superficiais, nesse nosso mundo que o Budismo chama de samsara, esquecem-se de ouvir e refletir sobre o verdadeiro sentido de suas vidas e do que se passa a seu redor. Assim, para Heráclito, tanto os poetas como os filósofos de sua época entregam-se exclusivamente a assuntos empíricos, a fenômenos transitórios e situações exteriores, deixando desse modo de atingir o logos, que, ao contrário, portanto, se supõe ser algo de estável, transempírico, e "interior". (ibidem, p.66).

Na Alegoria da Caverna, por outro lado, Platão nos mostra que com a luz do Sol tudo está presente, os homens podem enxergar a verdade fora deles. Vai dar trabalho, é difícil chegar lá, mas é possível conhecer. Quando o homem do fundo da caverna se solta e se vira na direção da saída, acontece uma revolução completa da alma porque até então ele acreditava que as sombras eram coisas reais. É uma reviravolta da alma, e a Paideia que Platão propõe é real, agora o homem pode caminhar para a verdadeira realidade, com confiança e sem medo. $\mathrm{O}$ que o pensamento platônico propõe é uma correção, uma exatidão, um mundo no qual não há mais ocultação e assim sendo não há 
mais desvelamento, agora as coisas se mostram claramente, com confiança. Afinal, o que é sair da caverna? Poderíamos perguntar. Sair da caverna seria um apurar dos conceitos para se ajuizar melhor o que acontece no interior da caverna e assim poder avaliar o que é a verdade diferentemente de sua sombra, é a verdade como adequação, é a coisa visível se adequando à Ideia, se adequando à coisa invisível, é a metafísica submetendo o mundo das aparências a esses padrões.

A alma platônica sempre está no registro da Ideia e é na sua Luz que a coisa tem a sua "presentificação" e só assim a compreendemos. No âmbito das Ideias tudo é presente, não há três dimensões, não tem como a alma não ver. Não há nada oculto. Saímos do desvelamento de Heráclito para a adequação em Platão. Para Platão essa ideia de adequação consiste na coisa estar em um modo de desvelamento que não pode ser questionado. A verdade como desvelamento é a interrogação de um chão fixo platônico. Heidegger mais tarde critica Platão e Sócrates por não terem prestado atenção a esse fundamento, para ele, tão esquecido na filosofia clássica. Critica a forma objetivadora como o ser foi tratado e percorre em suas reflexões um caminho de volta ao anterior, movimento esse que o leva na direção dos pré-socráticos, em especial a Heráclito.

Em Heidegger a verdade deixa de ter, como tinha no contexto da filosofia clássica, o sentido da correspondência, no sentido da adequação. Ao contrário de Platão, para Heidegger, a verdade é um processo de vir à luz do seu próprio ser, daquilo que ele é. Em Heidegger a verdade perde o caráter de engessado, de fixo e ganha o caráter de processo, como em Heráclito. A clareza do ser é o aparecer na luz, o tirar o véu, o surgir, o emergir. A verdade do ser é o vir aparecendo como ele é, é um vindo eternamente, um desabrochar em duplo movimento de clareira e ocultação, ou seja, o aparecer e o esconder, partes inalienáveis do processo de vir a ser.

Para Platão é diferente, há algo fora da caverna, que é a verdadeira realidade, independente se nós a vemos ou não, ela está lá. Platão afirma: Toma, esse é o real, esse é o chão. Desaparece por completo a verdade que interroga o chão, o fixo. Não há mais nada que interdite o conhecimento das coisas, como havia tão claramente na reflexão heraclítica, não há mais interrogação, é simplesmente o real em si mesmo. A Paideia de Platão é o caminho para a saída da caverna, em uma determinada direção, para o mais 
aberto, para a Luz, para o "Bem", para o caminho que tem um sentido claro e certo, sem interdição. É como se houvesse uma caminhada já decidida, primeiro você vê o reflexo na água, depois as imagens, para só então, mais tarde, ir vendo os objetos verdadeiros, como realmente são e desta maneira vamos caminhando e trocando coisas menos exatas por coisas mais exatas e assim chegamos ao conhecimento da verdadeira natureza da realidade. É como descrevem a linha dividida e a Alegoria da Caverna: das sombras ao "Bem”, o caminho está traçado, agora é só seguir para a grande Luz. A alma humana tem, para Platão, uma espécie de "olho intelectual", racional, que vê perfeitamente e desta maneira se inunda com a iluminação das Ideias.

Diferentemente, para Heráclito o ser carrega sempre a ocultação de algo que não se sabe. Na terminologia heraclítica, segundo Berge, cabe à inteligência humana desvendar a natureza. A physis, se oculta, retrai-se o divino, o saber... Alcança-o o logos, na reflexão abstrativa; não logra atingi-lo o adversário do logos, o homem mediocre, inábil, indigno dele (p.76). O senhor de quem é o oráculo de Delfos, não diz nem oculta nada, mas indica. (fragmento 93). O pensamento abstrato de Heráclito é descrito por Berge como uma descida a profundidades espantosas, a entrada em um mundo de zonas arriscadas. Não há nada às claras, como promete Platão. Para Heráclito não é através do olho que se chega à verdadeira natureza da realidade. Quem seguisse Heráclito havia de estar disposto a enfrentar toda espécie de incompreensões e resistências. Não haveria sentido certo e claro a ser trilhado. A revolução da alma platônica é algo inconcebível. A verdadeira natureza das coisas, a physis, está, pois, oculta e o homem mediocre detesta o estado de prontidão, recusa entrar no interior desconhecido e prefere o distanciamento de riscos e imprevistos, na verdade, adora a euforia esquecida dos problemas (exteriores) cruciais, apraz-se, do papel do inconsciente que, analogamente a quem dorme, não percebe como está próximo dele, na vida cotidiana, o logos com suas exigências (p.76/77). Para Heráclito o estado de inconsciência humana se assemelha à situação dos que dormem. Apesar de possuirmos uma capacidade pensante e termos como destino reconhecer o logos, não o percebemos. Essa inconsciência do homem precisa ser rompida: Não se deve agir como quem dorme, afirma Heráclito no fragmento 73. 
Se ouvirem, não a mim, mas ao logos, provarão ser sábios se admitirem que tudo é um (fragmento 50). Para Heráclito o sentido mais completo não é a visão, mas a audição. $O$ logos enuncia a verdade sobre a physis, tanto pela palavra interior, como pela exteriorizada, oral e escrita. Na constituição de ambas intervém decisivamente a audição... Quem não ouve não compreende. Pensar sensatamente é a mais elevada perfeição, e é sabedoria dizer a verdade e agir de acordo com a physis, ouvindo a sua voz (fragmento 112). Talvez podemos considerar que Platão esqueceu o valor da audição, apontada pelo pré-socrático, e declarou a visão como o sentido mais completo, é o Sol, a Luz, que concede a visibilidade às coisas, dando assim todo o poder ao sentido da visão. O Sol além de iluminar e revelar concede o crescimento através do calor que possui e arranca assim a verdade das coisas visíveis. Talvez possamos fazer uma leitura de que para Platão parece não haver uma interdição. 


\title{
3.2. A Interdição/Ocultação no Budismo
}

\author{
Há mais de 2 mil anos viveu Siddhartha, um príncipe indiano - \\ "Aquele cujo Designio será alcançado". Vivamente consciente do sofrimento humano, o \\ príncipe Siddhartha determinou-se a penetrar na causa raiz da frustração e da dor e a descobrir uma \\ maneira de viver mais profundamente satisfatória. Depois da realização de seu propósito, ele se tornou \\ conhecido como o Buddha, o desperto. \\ (Caminhos para a Iluminação, p.26).
}

De que lugar Buddha falava, o que havia ele descoberto ao se iluminar? Quais eram os referenciais desse lugar? Segundo Lama Padma Samten ${ }^{2}$, esse lugar de onde o Buddha fala é um lugar livre e sem condicionamentos.

Diferentemente de Buddha, estamos, nós, os pobres mortais, segundo a perspectiva budista, em outro lugar. Estamos imersos em dores e sofrimentos totalmente baseados em pontos fixos artificialmente construídos e condicionados. Criamos realidades exteriores que nos parecem sólidas, operativas e funcionais, mas que são, na verdade, apenas estruturas passageiras que nos levam a um aprisionamento. Em vários níveis de reflexões mais ou menos profundas, o Budismo aponta como esta busca de fixidez é exatamente o que vai originar a desarmonia e o sofrimento no qual estamos mergulhados. Buddha estrutura uma reflexão que brota de um lugar livre, a partir do qual ele pode observar como essas prisões e referenciais vão se estruturando, se somatizando e acabam por compor o nosso próprio corpo, o mundo a nossa volta e a noção, para nós, definitiva, de que existe uma linearidade de vida e morte.

Vivemos dentro de uma realidade construída, como se fosse uma bolha transitória, construída conscientemente ou não, mas construída. Essas bolhas de realidade surgem, segundo o Budismo, nos dando a sensação de que elas são reais, mas são apenas bolhas de realidade, independentemente de seus conteúdos são apenas bolhas. Houve uma época em que essas bolhas estavam em cada vale, em cada tribo, em cada vilarejo, hoje estamos juntando todas as bolhas que estão se transformando em uma grande bolha. Vivemos esses referenciais como paisagens mentais que mudam a

\footnotetext{
${ }^{2}$ Este capítulo foi inspirado nas palavras do Lama Padma Samten, do Centro de Estudos Budistas Bodisatva, CEBB, mais especificamente na palestra sobre Budismo, Meditação, Compaixão e Transformação Interior e o Pensamento Budista, no Curso de Extensão, Diálogos entre Oriente e Ocidente, da PUC-RS, de 4 de junho de 2016.
} 
todo instante, que são as bolhas transitórias; mas não sabemos operar de outra forma que não seja dentro dessa bolha de referenciais.

Buscamos verdades definitivas e pontos fixos nos quais possamos nos apoiar. Fugimos das mudanças e das contradições. Corremos atrás de uma salvação referencial, um mestre, uma verdade na qual possamos nos fixar. Mas assim parece que agimos como quem dorme ao negar as constantes mudanças de tudo a nossa volta. Construímos a nossa realidade onde estamos operando, mesmo sabendo que tudo no mundo e até mesmo as visões filosóficas estão e foram mudando o tempo todo. A cada época nós vemos como se fosse uma realidade sólida, mas não é uma realidade sólida, é uma realidade construída. Vivemos hoje em uma realidade tecnológica, mas nem sempre foi assim e não será assim no futuro. Tudo muda, dentro de uma mesma linha de tempo manifestamos diferentes realidades, desenvolvemos um sentido de verdade a partir de bolhas que impregnam o nosso olhar, a nossa criatividade e determinam a nossa ação no mundo. Estamos como em um sonho, somos seres de sonho. Vivemos em uma desarmonia natural, convivendo com o choque inevitável que acontece entre os nossos sofrimentos de sonho. Essa noção parece estar presente também em Heráclito:

Para os que estão acordados, há um só mundo comum; (mas, dos que dormem, cada qual retorna para seu mundo) próprio. (fragmento 89 de Heráclito).

Mas como podemos operar livres dessas bolhas de realidade?

Buddha através de seus ensinamentos nos mostra como poderemos ultrapassar essas bolhas de realidade e ajudar outras pessoas também a sair delas. Dentro das bolhas de realidade temos as contradições e o sofrimento e Buddha nos aponta como estamos totalmente submetidos a esse aprisionamento da dor e da mudança. Ele nos ajuda a compreender a partir desse ponto onde estamos. Os indivíduos são propelidos, pela força de suas ações a continuamente repetir padrões que os aprisionam a infindáveis ciclos de nascimento e morte. O Iluminado viu que tudo que forma nossa realidade está em um estado de fluxo contínuo. Toda a existência - de indivíduos, nações e culturas, até a terra mesma com a qual contamos -, está sujeita a mudanças. (Caminhos para a Iluminação, p. 87). No curso do tempo, civilizações inteiras desenvolvem-se e desaparecem, fortunas individuais aumentam e diminuem, impérios ascendem e decaem 
e o pleno significado de tal impermanência que tudo permeia é um profundo e interminável sofrimento (ibidem, 87). Neste ponto não podemos, novamente, deixar de lembrar Heráclito: Não se pode descer duas vezes para dentro do mesmo rio (nem tocar duas vezes a mesma substância perecedora enquanto mantém o mesmo modo de ser, pois pela veemência e rapidez de sua transformação, ela) se dispersa e torna a congregar-se, aproxima e distancia-se. (fragmento 91). O Budismo traz a ideia da transmigração, estamos obrigados a transmigrar, a mudar, a passar de um estado a outro, de uma situação a outra; como um pássaro, os homens voam de galho em galho na busca de um galho salvador, de um galho prometido que, afinal, nunca chega.

O Budismo propõe, então, que olhemos para esse ciclo transitório no qual vivemos, não partindo do sofrimento e da mudança, mas partindo de uma perspectiva mais ampla, olhando "de cima para baixo", percebendo que existe algo de permanente além das bolhas. Para Heráclito também haveria algo de permanente, algo que se oculta por entre as coisas que mudam a nossa frente. A harmonia invisível é superior a visível (fragmento 54). A rota para o alto e para o baixo é uma e a mesma (fragmento 59) É preciso ultrapassar essa interdição, segue o Budismo, tentar chegar em um plano mais livre, alcançar uma consciência mais ampla. Propõe que se olhe para as bolhas de realidade sem ficar fixados a elas, para que possamos encarar as contradições sem as considerar problemáticas. É preciso ver as contradições como totalmente naturais. É preciso entender que vivemos entre opostos; em toda a biosfera diferentes grupos de animais se beneficiam e se prejudicam uns aos outros, precisamos comer uns aos outros para conseguirmos sobreviver, vivemos todos em constantes relações contraditórias que geram sofrimentos inevitáveis. O sofrimento é uma natural contradição que ocorre em todos os níveis nos quais podemos nos movimentar. Vivemos sempre o choque das diferentes estruturas, vivemos em plena guerra entre os opostos, afirma Heráclito. Pólemos [a guerra] é pai de todas as coisas, rei de tudo, a uns, os demonstrou como deuses, a outros como homens; de uns, fez escravos, de outros livres. (fragmento 53). $O$ deus é dia-noite, inverno-verão, guerra-paz, saciedade-fome. Varia como o fogo, o qual, ateado a especiarias, é denominado conforme o perfume destas. (fragmento 67).

Há, entretanto, algo permanente, que é justamente o que se mantém operativo no final de uma bolha e que permite a construção de outra bolha. Se eu estou em um 
galho e vou esvoaçar em direção a outro, diz o Budismo, eu estou levando alguma coisa que não pertence nem a um galho nem ao outro. O que haveria de profundo além das bolhas e dos galhos e das identidades ilusórias? Há de haver algo contínuo para que eu possa manifestar diferentes realidades. Há algo contínuo que me permite dizer que passei de uma realidade a outra, mas o que há de contínuo dentro disso?

Dentro de uma perspectiva mais ampla, olhando "de fora", "de cima para baixo" o Budismo propõe que se averigue: como a minha mente está operando dentro dessas bolhas? Como é que ela se fez como uma mente de uma bolha? Como é que eu vejo a mente de uma bolha sem estar sob o poder de uma própria bolha? Entretanto, quando começamos a olhar as bolhas fora das perspectivas das bolhas pode ser que estejamos em bolhas maiores, mais amplas, mas ainda bolhas. Mas dentro de uma perspectiva Budista podemos alcançar um ambiente livre, progressivamente mais livre e mais lúcido, que o Budismo irá chamar de sabedoria primordial, que é o que o Buddha atingiu em sua Iluminação. Seria o potencial que todo ser humano tem de ser livre.

E é através da meditação que o Budismo acredita que se consiga convergir na direção de um movimento de permanecer estável fora da bolha, superar as contradições, as oposições e alcançar o permanente. Por outro lado, para Heráclito a liberação da interdição é através da reflexão abstrativa; Berge (p.78) ressalta que para a própria doutrina heraclítica seu logos visa a três fins: 1. evocar a reflexão; 2. promover o pensamento abstrativo e universalizante, acesso único à physis; e 3. conduzir à ação reta, enquanto que para Buddha é através da Meditação: Apenas sente, deixe ser o que é. Deixe que a meditação se faça por si mesma. Depois de ter aprendido a deixar os pensamentos passar por você, eles diminuem de velocidade e quase desaparecem. Então, atrás do fluxo dos pensamentos, você sentirá uma sensação que constitui a base da meditação. Você talvez tenha uma leve noção de algo permanente. Quando entrar em contato com esse lugar silencioso que há por trás de seus diálogos internos talvez consiga alcançar a tão desejada estabilidade e possa repousar nessa quietude. $O$ silêncio interior que brota da meditação alivia a tensão destes tempos de mudanças rápidas, em que é tão fácil perdemos nosso senso de estabilidade e de equilíbrio. (Tarthang Tulku, 1978, p.43). 
Sabemos que as contradições existem, estamos andando em um território contraditório, mas o Budismo instrui: pense além do pensar, vá além das bolhas, alcance uma base que é a liberdade dos próprios pensamentos, tome posse desse espaço entre os pensamentos e o amplie. Na meditação progressivamente vamos nos deslocar para uma posição na qual vamos repousar além das bolhas e quando entendermos isso poderemos talvez entender como as bolhas são construídas, que na verdade elas surgem a partir desse espaço e a partir da luminosidade da mente. Veremos, afirma o Budismo, que as bolhas na verdade não obstaculizam a própria mente ampla. A mente ampla não é a que está fora das bolhas, ela está fora, mas também dentro das bolhas, não há nenhum momento em que elas não estejam ali. As aparências não são para o Budismo um obstáculo, mas uma manifestação dessa mente ampla.

Através da reflexão abstrata para Heráclito e da meditação para o Budismo passamos a entender que a interdição faz parte dessa mente mais ampla e que não estamos condenados a obedecer a essas estruturas transitórias. Da meditação budista brota então um ponto ainda mais amplo e aí surge a Compaixão, que é a compreensão de que todos os seres estão presos a coisas desse tipo, que estamos todos nos conectando a coisas e a estruturas físicas e emocionais imaginando que elas sejam reais e estáveis, acreditando que elas sejam soluções para nossos sofrimentos. Surge assim a natureza de Buddha, a natureza ampla, um lugar de amor no qual não há mais nenhuma cobrança, ou seja, a alegria do outro é o pagamento justo para nós, o beneficio que o outro tem que talvez ele nem reconheça é o pagamento justo e completo da nossa ação. Com a compaixão e o amor surge a compreensão do que seja a Iluminação Budista que todos podem alcançar. 


\subsection{A Interdição/Ocultação em Heráclito}

A physis tende a ocultar-se (fragmento 123 de Heráclito).

No pensamento jônico dos séculos VI e V a.C. cruzam-se duas correntes, uma da cosmogonia empírica, mestres como Tales e Anaxímenes, que observam pormenorizadamente numerosos fenômenos da natureza e do organismo humano e que querem saber a verdade. Outra corrente, como o mestre Anaximandro, que não desconhece os elementos empíricos, mas que se dedica ao pensar abstrato. É nesse ambiente de pesquisas e especulações que se encontra Heráclito que está a par tanto das teorias científicas como do pensar abstrato, mas que demonstra extraordinária força intuitiva e aptidão para o transensível. Heráclito com toda a sua energia inteligente e passional quer orientar o pensar e o agir daquela juventude pelo logos profundo, induzindo-a a compreender e seguir esse logos. O logos é o princípio vital de tudo e de todos: reconhecê-lo e segui-lo, esta é a atitude correta (Berge, p.70).

Do logos, a ser exposto neste livro, e que existe e vale sempre, os homens são sempre ignorantes, quer antes de o terem ouvido, quer apenas tenham começado a percebê-lo. Pois, embora tudo proceda de acordo com esse logos, eles se parecem com gente sem experiência, cada vez que experimentam falas e atos do gênero que exporei, analisando cada coisa segundo sua physis e interpretando-a como é. Aos demais homens oculta-se o que fazem quando acordados, assim como se esquecem do que praticam quando adormecidos (fragmento 1).

Há no fundo de cada atitude uma convicção doutrinária que ou é favorável ao logos ou o hostiliza. Para Heráclito, a verdade só aparece através do logos, nos enunciados e nos atos por ele dirigidos. Do lado oposto, encontram-se os épea $e$ érga, (Nota 3.) as falas e as ocupações que aparentam um saber certo e um agir prodigioso, mas, na realidade, são erro e inércia (ibidem, p.71). O logos se apresenta como portador de um certo sentido, vítima do comportamento errado dos homens, princípio vital e inteligente do pensar e do agir humanos, dirigente de tudo e de todos, superior ao sensivel e ao exterior (ibidem, 72).

nota 3. Há para Heráclito uma mediocridade, que não está restrita a nenhuma classe social, mas que existe em todas as classes. Sua existência e suas qualidades são demonstradas empiricamente, através da conduta de seus representantes. Este comportamento permite estabelecer: 1. Que o linguajar deles, o épos, é superficial e inexpressivo, sintoma de inabilidade mental; 2. Que o seu agir, o érgon, se processa numa difusão ineficiente, prova da ausência de uma ética firme; 3. Que ele próprio, o vulgo, é a corporificação da mediocridade (Berge, p.76). 
Demócrito, pouco mais tarde, define a palavra logos como "revela". Evidentemente, só pode revelar-se o oculto invisível. Mais adiante, também Aristóteles retoma essa explicação do termo dizendo que o logos "revela, demonstra algo". $\mathrm{Na}$ interpretação desta frase, feita por Heidegger, aparece, clara e nítida, a posiçãofunção do logos: falando, ele torna visível o invisível sobre o qual se pronuncia (ibidem, p.73).

Há, portanto, para Heráclito, uma ocultação, algo está interditado, não é visto, não é sabido, somos ignorantes de algo, é preciso desvelá-lo. E o logos é o enunciado, o discurso que torna visível o invisível, ou seja, o logos revela a physis e A physis tende a ocultar-se (fragmento 123). O termo physis carrega consigo o mito antiquíssimo que faz tudo que existe vir de um fundo comum, ser originário de um eterno "substrato" primordial. O pensamento jônico começa a dar uma explicação racional àquilo que o mito anteriormente expressava por meio de teogonias.

\begin{abstract}
Os seres "procedem" não do nada, mas "de dentro de si mesmos", isto é, através de causas naturais, regidas por leis imanentes. Este processo espontâneo pelo qual "algo vem a ser", "nasce" ou "cresce", phyetai, e assim "é e existe" - não devido a uma intervenção extrínseca, mas em virtude de sua própria força -, este processo, pois, é a physis... é o primário, em oposição ao secundário e derivado; o sempre permanente, substrato fundamental dos fenômenos transitórios; sujeito último a subsistir em tudo mais... (ibidem, p. 74).
\end{abstract}

Heráclito afirma a interioridade e a invisibilidade, mas isto não quer dizer que tenha contestado o mundo exterior, só não considera o extrínseco como o ser completo. Há para Heráclito um interior, um interditado, uma ocultação, a physis, que está encoberta pelo empírico secundário e que precisa ser desvelada. Para Heráclito a physis só se revela no $\log o s$ e a sua descoberta exige um grande esforço pensante abstrato e que ainda supõe uma nobre elevação moral. A presença da ignorância e da mediocridade resulta da carência de reflexão abstrativa e de ética e representa uma grande interdição que requer um árduo esforço e um enorme enfrentamento de incompreensões e resistências. Enquanto o Budismo fala que vivemos dentro de bolhas de realidade, Heráclito fala de uma inconsciência humana. Apesar de tudo ser dirigido 
pelo logos e de sermos todos regidos por ele, algo de muito singular acontece: apesar desse estreito convívio, os homens ignoram a sua existência. Assim observa Heráclito no fragmento 72: Daquilo, com que mantém contínuo contato, do logos, discorda; e as coisas que encontram diariamente parecem-lhes estranhas. Estamos como anestesiados, em um estado de inconsciência humana, semelhante à situação do sono. $\mathrm{O}$ homem perde o uso da razão, vindo a recuperá-lo depois de acordado. Mas, entretanto, para Heráclito mesmo depois de acordados continuamos como quem dorme, isto é, continuamos a não nos servirmos da capacidade reflexiva. (ibidem, p.77). Essa inconsciência precisa ser rompida, segundo o fragmento 73: Não se deve agir nem falar como quem dorme. 


\subsection{Semelhanças entre as visões de Buddha e de Heráclito}

Busquei-me a mim mesmo. (Heráclito, fragmento 101).

A meditação nos permite entrar diretamente em contato com nossa natureza pura e descobrir a qualidade desperta que está sempre disponível em todos os momentos de nossas vidas (Tarthang Tulku,

Na história do pensamento humano, sabemos que Heráclito (cerca de 544/1 até 484/74) ficou conhecido como o enigmático, o obscuro e não ocupou, durante muito tempo, posição propriamente prestigiosa. Deixou a impressão, como ressalta Berge, de ser um perigoso relativista, iniciador da doutrina de que nada na verdade existe de certo e de que tudo está em contínuo fluxo. Foi visto por muitos como um pessimista incorrigível e de leitura difícil (p. 11). Contudo, os mais distintos mestres continuaram a apreciá-lo. Para muitos Heráclito é realmente belo. Muitos acreditam que, se ele tivesse nascido na Índia ou no Oriente, teria sido considerado um Buddha. Mas, na história da Grécia, para a filosofia grega, ele não é conhecido como o Iluminado, mas como o Enigmático, o Obscuro, no máximo um poeta, apesar de ter escrito em prosa. Mas, Heráclito não é obscuro, apenas não estamos acostumados a tanta luz e por isso teremos que fazer alguns ajustes antes de compreendê-lo.

Buddha (961 a.C.), pelo contrário, foi, e até hoje é conhecido como a Luz do Mundo. Nasceu como Siddhartha, um príncipe indiano - “Aquele cujo Desígnio será alcançado". Vivamente consciente do sofrimento humano determinou-se a penetrar na causa raiz da frustração e da dor e a descobrir uma maneira de viver mais profundamente satisfatória. Depois da realização de seu propósito, ele se tornou conhecido como Buddha, o Desperto (Caminhos para a Iluminação, p.26).

Heráclito, o Obscuro, e Buddha, o Iluminado, aparentemente não poderiam ser mais diferentes, se levarmos em conta como eram chamados. Entretanto, na medida em que seus ensinamentos desabrocham a nossa frente emergem claramente as suas semelhanças, muito mais do que as suas diferenças. Parece evidente a semelhança entre o pensamento iluminado de Buddha e as elaborações filosóficas de Heráclito. Mas, fica claro também, como os dois mestres foram, no seu tempo, compreendidos de maneira tão diversa por seus contemporâneos. Talvez possamos afirmar que os gregos ficaram 
assustados diante de Heráclito, talvez porque ele abre, assim como Buddha, a porta da vida, e a vida é paradoxal, Buddha também é paradoxal, Lao Tsé, o mestre chinês é paradoxal, todos os que sabem são paradoxais... A vida é paradoxal.

A vida não é lógica como queria Aristóteles.

A vida é enigmática e Buddha e Heráclito são enigmáticos.

Ambos falam na busca desesperada dos homens por uma estabilidade, queremos que o mundo nos dê segurança, mas a vida existe através das contradições, através da tensão dos opostos e eles parecem ter compreendido claramente essa mutabilidade. Sabiam que era necessário movermos para o oposto, para então, podermos retornar novamente. Sabiam que a vida persiste através de um movimento constante e que qualquer coisa fixa e estabelecida está morta. Sabiam que estar vivo é mover-se entre os opostos. Para Heráclito, viver é um eterno vir-a-ser, tudo está crescendo, movendo-se. Buddha sabia o quão fútil e vazia a vida pode ser quando nos apoiamos na falsa crença de continuidade e permanência.

Heidegger, mais tarde, elabora seu pensamento filosófico moderno a partir dessa ideia dos opostos e da tensão entre eles, tudo que se manifesta traz consigo o vir aparecendo e o não aparecendo, a clareira e a ocultação, a luz e a sombra, o côncavo e o convexo, o haver e o não haver, a inspiração e a expiração, a vida e a morte... A manifestação do ser implica em aparecer e não aparecer ao mesmo tempo. Essa é a physis para Heidegger, o jorrar que envolve ocultação e manifestação. Uma parte a mostra e outra parte oculta. Heidegger herda o ser de Heráclito, ou seja, esse jogo invisível que aparece e desaparece e que é o que o budismo chama de impermanência.

A physis, para Heidegger, é essa força invisível, a do emergir, a do deixar vir à presença. O filósofo volta aos pré-socráticos a fim de resgatar esse fundamento jorrante, que foi esquecido e que ele chama de busca do sentido do ser; e esse ser, do pensamento pré-socrático, que é anterior aos deuses, anterior a tudo. Heidegger se inspira em Heráclito que afirmava que a physis tende a ocultar-se ( fragmento 123), que a natureza não está na superfície e sim oculta no centro. É como a raiz das árvores, profundamente enterrada - o mais essencial está oculto. Nunca pense que a árvore é o mais essencial. A árvore é apenas a periferia, onde as flores, as folhas e os frutos surgem. A árvore real 
está no escuro, sob o solo. No útero escuro da terra, ela se oculta. O pensamento de Heráclito e de Heidegger tem muito em comum, não só com o pensamento budista, mas também com o pensamento oriental de mestres hinduístas. Talvez possamos afirmar que a ideia oriental do voltar-se para dentro de si mesmo da meditação budista e a noção de Heidegger de uma dimensão oculta fundamental são noções também facilmente detectadas em fragmentos do filósofo pré-socrático grego: Busquei-me a mim mesmo. (fragmento 101). Há a noção de dentro de si mesmo, de recolhimento, de silêncio e de ocultação.

Para o Budismo, a razão mais profunda de termos medo da morte é que não sabemos quem somos e não temos o hábito de nos buscar a nós mesmos como aconselha Heráclito. Acreditamos em uma identidade única e separada, mas se ousarmos examiná-la descobriremos que essa identidade depende inteiramente de estruturas construídas que nos sustentam: nosso nome, nossa família, nosso emprego, nossos amigos... Nossas bolhas de realidade. E é nessa estrutura frágil e impermanente que apoiamos nossa segurança. Assim, o que acontece quando tudo isso nos é retirado, e ficamos cara a cara conosco, com alguém que não conhecemos, um estranho amedrontador com o qual estivemos convivendo todo o tempo, mas que nunca desejamos realmente encontrar? Vivemos cada minuto com barulho e atividades ainda que sem graça e artificiais, pulando de uma bolha de realidade para outra bolha de realidade, para nos assegurarmos de nunca ficar em silêncio frente àquele estranho que há em nós mesmos. (Sogyal Rinpoche, 1999, p. 35).

Para Heráclito vivemos como quem dorme, para o Budismo vivemos dentro de bolhas transitórias de realidade, sob uma identidade presumida e isso pode nos parecer maravilhoso até que nos deparamos com a morte. É quando a ilusão é destruída e somos obrigados a sair de nosso abrigo e deixar tudo para trás. Somos, para Heráclito, vítimas de uma ignorância, de uma inconsciência humana, (fragmento 1), para o Budismo vivemos como uma pulga, saltando sem cessar de um lado para o outro. Vivemos com pensamentos que surgem desconexos, sem razão nenhuma, somos levados de roldão pelo caos de cada instante, somos vítimas da inconstância da nossa mente. Para o Budismo, podemos estar vivendo no samsara, uma vida vazia e fútil, nos apoiando na falsa crença de continuidade e permanência (ibidem, p. 36/37). A causa fundamental do 
sofrimento é para o Budismo, assim como para Heráclito, a ignorância. Há nas escrituras budistas relatos que se referem a nossas vidas como se estivéssemos "entrando em uma densa floresta pela estrada errada", mas a direção já está estabelecida e nós seguimos uma estrada bastante trilhada. Mesmo que possamos divagar se o caminho que tomamos está nos levando na direção em que queremos ir, achamos mais fácil trilhar uma rota que nos parece familiar do que embrenhar-nos floresta adentro para explorar caminhos alternativos. Este ignorar e essa relutância em investigar são as características básicas de nosso modo de vida. (Caminhos para a iluminação, p.90). Heráclito também afirma que estamos caminhando na direção errada e que esquecemos que estamos perdidos no meio da estrada sem saber ao certo a direção para onde desejamos ir. É preciso recordar-se também de quem se esqueceu para onde conduz a estrada (fragmento 71). Apesar de terem ouvido, não têm compreensão: parecem-se com surdos. O provérbio o atesta: presentes, <estão> ausentes. (fragmento 34). 


\subsection{Visões Metafísicas como apenas apreensões parciais da realidade}

Espíritos meditativos não costumam apreciar observadores inquietos (Berge, p.77).

Não sabemos o ano exato do nascimento de Heráclito assim como também não sabemos de todos os pensadores, poetas e historiadores arcaicos, cuja cronologia só podemos presumir. Entretanto, sabemos que Heráclito viveu em uma época política e economicamente agitada e notável pelo surto de um pensamento racional. Podemos afirmar, contudo, que Heráclito era demasiadamente independente, conhecia a fundo a literatura e o pensamento anteriores, desde Homero e Hesíodo, estava a par de todas as inovações e tendências científicas de seus contemporâneos jônicos, mas, era diferente de todos. Nenhuma documentação nos permite ter certeza a respeito de seu posicionamento político, mas seu desprezo pelo vulgo talvez possa ser compreendido não como um desprezo por uma classe social, mas, por um comportamento. Desprezava a atitude mental dos homens que não se esforçavam por ir além da aparência extrínseca das coisas (Berge, p.51/52). Seu racionalismo, porém, não é o do empirismo jônico: conduz ao pensar metafísico, razão por que ele ataca rudemente os cientistas de sua terra (ibidem, p.54). Para Berge, Heráclito parece não ter compreendido a fundo o valor intrínseco das novas ciências jônicas e o progresso intelectual que representavam. Espíritos meditativos não costumam apreciar observadores inquietos. Mesmo assim, prossegue Berge, vibra na unilateralidade de Heráclito a preocupação nobremente intencionada, de que o novo surto científico viesse a efetuar-se à custa da ascensão transempírica que, por sua vez, também estava apenas ensaiando suas primeiras experiências (p.77).

Para Hajime Nakamura, renomado estudioso e tradutor das escrituras budistas, o jovem príncipe Siddharta Gautama (563-483 a.C.), o fundador do Budismo, também poderia ser considerado um espírito meditativo que não apreciava observadores inquietos, e que questionava o rumo que os estudos do hinduísmo estavam tomando entre os seus contemporâneos. Segundo Nakamura, Siddharta/Buddha reparou que havia uma grande disputa entre vários sistemas filosóficos, na qual cada pensador 
reivindicava para si uma verdade absoluta acusando os outros de seguirem doutrinas que continham inverdades baseadas em falsos problemas. "O que eu digo é verdade, a realidade que o outro diz é falsa; e assim discordando eles disputam”. Por que os pensadores não dizem a mesma coisa? Indagava um discípulo. (Sutta-nipata 883). E Buddha afirmava: Aqui há pureza; em outras doutrinas, não há pureza; àquilo a qual eles se dedicam eles chamam de verdade, e mergulham exaustivamente em suas verdades únicas (Sutta-nipata 824). Porque ele considera o outro um tolo ele se considera um esperto; em sua opinião é ele quem está falando a coisa propícia; aos outros ele censura. (Sutta-nipata 888). (Nakamura, p.217). Nakamura cita aqui trechos da fala de Buddha retirados de escrituras budistas, originalmente escritos em versos e que relatam prescrições religiosas e valores éticos ao mesmo tempo em que pretendem descrever uma maneira de perceber a vida, seus problemas e suas soluções. Nos versos do Sutta-nipatta (883-824-888) Buddha relata a sua insatisfação com as disputas filosóficas durante as quais os homens disputavam quem seria o verdadeiro conhecedor da verdadeira natureza da realidade.

O Sutta-nipatta e o Dhammapada são escrituras budistas, antigos dizeres de Buddha traduzidos do cânone da língua arcaica indiana, Pali, conhecidos como os Pali cannon, através dos quais temos acesso aos ensinamentos budistas. Buddha, prossegue Nakamura, acreditava que os filósofos hindus da sua época entravam em disputas a respeito de vários problemas metafísicos insolúveis e se emaranhavam em apego ou fidelidade e a partir daí ficavam vulneráveis a cair em infortúnios morais: "Afirmando que existe algo firme em seu caminho, ele enxerga seu oponente como um tolo; provocando ele mesmo um conflito, uma luta, uma discussão ao chamar seu oponente de tolo e impuro" (Sutta-nipata 893). Buddha afirmava que eles eram inflamados, incendiados por suas próprias visões filosóficas (Sutta-nipatta 891).

Segundo um determinado ponto de vista, talvez, podemos considerar que os contemporâneos hindus de Buddha estariam da mesma maneira que os contemporâneos gregos de Heráclito buscando afirmar uma determinada visão filosófica com o intuito de superar o mistério que interdita o conhecimento da verdadeira natureza da realidade. Ao se fidelizarem e se apegarem a uma determinada visão filosófica metafísica estariam 
talvez querendo afirmar uma fixidez e a possibilidade da capturarmos "a verdade" através de um pensamento racional, direto e claro.

Mas assim como Buddha, Heráclito parece ter apontado para essa situação problemática, na qual os homens buscavam desesperadamente se apegar a uma compreensão extrínseca determinada, disputando assim o título daquele que finalmente encontrou "a verdade da vida", sem perceber o que estava a seu lado: A grande multidão não entende essas coisas, apesar de sempre encontrar-se com elas; percebendo-as, não as compreende <em verdade>, mas imagina-o (fragmento 17). Tanto para Buddha como para Heráclito, os homens estariam preocupados com falsos problemas, defendendo um determinado ponto de vista como se fôssemos capazes de conhecer facilmente, através da razão, a verdadeira natureza da realidade.

Apesar de estarmos plenamente conscientes da enorme dificuldade em compreender a fundo e em toda a sua extensão as reflexões dos dois mestres, talvez possa haver um entendimento de que tanto Buddha quanto Heráclito ressaltavam essa noção de ignorância no sentido de que os homens muitas vezes fazem afirmações a respeito da verdadeira natureza da realidade sem reconhecerem a interdição, ou seja, sem admitir que há algo que se reserva, que há um árduo e longo caminho a ser percorrido, uma vez que estamos longe de superar a imensa ignorância humana que temos diante de nós.

Buddha através de seus ensinamentos procura nos fazer entender a importância de superarmos essas disputas, e com seus dizeres ele nos mostra que a questão não é quem tem razão, não é quem descobriu como superar a interdição, quem está certo e quem está errado; ele nos ensina que deixando para trás as determinações, não instigamos conflitos no mundo. (Sutta-nipata 894). (Nakamura, p.218). Talvez neste ponto, podemos afirmar que não há, para ambos, determinações a serem afirmadas categoricamente, algo fixo no caminho. E, é na verdade a busca desesperada, a defesa excessiva de pontos de vista imutáveis e intransigentes e o apego a doutrinas e verdades únicas que nos levam à dor e ao sofrimento. Uma vez admitida esta compreensão, talvez possamos afirmar que para o Budismo as visões metafísicas são apenas apreensões parciais da verdade que está muito além da nossa área de cognição, muito além de uma análise racional. 
Há relatos de analogias que Buddha fazia para explicar essa sua percepção de que não se conseguiria ter uma apreensão total da verdadeira natureza da realidade através de uma experiência empírica e racional: A parábola "Os cegos e o elefante", na qual ele faz uma metáfora com as discussões entre os Brâmanes e os ascetas, nos descrevendo bem seus ensinamentos: Alguns dizem: o mundo é eterno, outros respondem; o mundo não é eterno; alguns afirmam: corpo e alma são separados, outros discordam: corpo e alma são apenas um...: Parábola hindu - Os cegos e o elefante:

Em uma cidade na Índia viviam sete sábios cegos. Embora fossem amigos, havia uma rivalidade entre eles, que discutiam frequentemente sobre qual seria o mais sábio. Em uma dessas discussões para saber quem sabia mais, o sétimo sábio irritou-se com tanta discórdia e resolveu se afastar do grupo e se isolar em uma caverna na montanha. Um dia chegou à cidade um comerciante montado em um enorme elefante. Os cegos sábios nunca tinham tocado nesse animal e correram para a rua ao encontro dele. $\mathrm{O}$ primeiro sábio tocou na barriga do animal e declarou: "Trata-se de um ser gigantesco e muito forte". O segundo sábio tocando nas presas do animal disse: "Que bobagem, trata-se de um animal pontiagudo como uma lança". Ambos se enganam, disse o terceiro apalpando a tromba do animal: "Esse animal é idêntico a uma serpente sem dentes". O quarto que mexia nas orelhas, afirmava que se tratava de um animal bamboleante, como se fosse uma enorme cortina ao vento. O que tocava na cauda, irritado afirmava que estavam todos enganados: "Esse animal é como uma rocha na qual há uma corda presa". Enquanto que, aquele que abraçava a pata do elefante o descrevia como um tronco de uma árvore robusta e antiga. E assim, ficaram horas debatendo, aos gritos com suas certezas inabaláveis... Até que chegou o último sábio que, descendo a montanha, acompanhado de uma criança, pediu ao menino que desenhasse o contorno do animal na areia e tateando o desenho pode constatar que todos estavam errados e certos ao mesmo tempo. É assim, ensinava Buddha, que os homens se comportam perante a verdadeira natureza da realidade, pegam apenas uma parte, pensam que é o todo e continuam tolos.

Para o Budismo esta parábola representa a visão das muitas afirmações de verdades parciais defendidas pelas diferentes escolas da antiguidade. Homens que apreenderam apenas essa ou aquela pequena parte da verdade, disputam uns com os 
outros, e suas análises racionais são úteis apenas para deixar bem claras as limitações da racionalidade. Para Buddha é apenas se descolando das oposições metafísicas, saindo das bolhas de realidade, que poderemos alcançar a verdade por inteiro, a sabedoria primordial. Os pensamentos de filósofos ocidentais arcaicos como Aristippus e Heráclito são, segundo Nakamura, os que mais provavelmente se aproximam da doutrina de Buddha da visão parcial da verdade. (p.219/220). Heráclito: A polimatia não ensina a ter compreensão. Do contrário, tê-la-iam ensinado Hesíodo, Pitágoras, Xenófanes e Hecateu. (fragmento 40). Pitágoras, filho de Mnesarco, fez entre os homens, as mais numerosas pesquisas; selecionou livros e deles compôs seu saber próprio: polimatia, charlatanice. (fragmento, 129).

De acordo com as escrituras budistas, Buddha não dizia: minha doutrina está certa, assim como não dizia: a sua é falsa. Os ensinamentos de Buddha transcendem as comparações, não é superior, nem igual e nem inferior às outras doutrinas (Sutta-nipata 855,860). O Budismo parece se recusar a dar respostas definitivas na maior parte das questões metafísicas. Se o mundo é eterno ou não; se o mundo é finito ou não; se a alma é igual ou diferente do corpo; se um santo existe depois da morte... As respostas para todas essas perguntas metafísicas não deixaria, segundo o Budismo, tempo para o que na verdade realmente importa que é encontrar um meio de salvação e liberação do sofrimento. O Budismo ilustra essa noção de urgência em acabar com o sofrimento com a parábola do homem ferido com a flecha envenenada: Um homem é ferido com uma flecha envenenada, mas antes de tirarem a flecha de seu corpo, ele diz: "Parem, não mexam na flecha, quero antes saber algumas coisas: Antes de vocês tirarem essa flecha envenenada do meu corpo eu preciso saber: Quem a atirou? O porquê dessa atitude? Foi um guerreiro ou um Brâmane? Ou teria sido um escravo? Qual a sua casta? A que família ele pertence?..." O Budismo ensina: antes que todas essas perguntas fossem respondidas o homem com certeza teria morrido. Do mesmo modo o discípulo que quiser respostas para todas as perguntas sobre o absoluto e o além do absoluto, também irá morrer antes de descobrir a verdade sobre o sofrimento (Nakamura, p.225).

$\mathrm{Na}$ época de Buddha, a Índia abrigava muitos sistemas de práticas meditativas e numerosas filosofias especulativas, incluindo formas de teísmo, ceticismo, materialismo, hedonismo e fatalismo. Siddharta/Buddha procedeu à investigação de 
todas elas e tinha um teste muito claro que aplicava a cada tradição: "Traz a utilização desse ensinamento um fim a frustração e ao sofrimento?" Ele não encontrou nada, nenhuma filosofia que conduzisse à completa cessação do sofrimento. Seguido por cinco ascetas atraídos pela sua busca, Buddha desiste de professores e continua a sua busca espiritual por si só. (Caminhos para a iluminação, p.31).

Para Nakamura, (p. 226), de acordo com o Budismo não devemos discutir sobre coisas que não temos uma boa evidência, não há tempo para discussões metafísicas, é preciso tirar a flecha envenenada. Para Heráclito: Não façamos, inconsideradamente, conjeturas sobre os assuntos mais elevados (fragmento 47). O Budismo despreza as especulações metafísicas em favor de preparar os homens para serem capazes de por um fim a dor e aos seus sofrimentos. E essa atitude indiana em deter as discussões metafísicas parece encontrar um enorme paralelo na Grécia com Heráclito, que lastimava o caráter hermético das afirmações dos filósofos a respeito da verdade: Não podes, andando, encontrar os confins da psique, ainda que percorras todas as estradas: tão profundo logos ela possui, (fragmento 45).

A filosofia ocidental é marcada pela discordância, o primeiro discípulo discordou do primeiro mestre e essa discordância não é uma mera contingência. Sabemos que o discurso filosófico é o mais individualizado que se tem noticias, por mais que o sábio afirme algum pensamento, alguma ideia, o aluno vai sempre pesquisar por conta própria. O que temos, na verdade é uma tradição de desestabilidades e discordâncias. Qual é o critério de conhecimento? O que é o conhecimento? Como posso afirmar o que está certo e o que está errado? Quem conhece de fato? Dá realmente para conhecer? Há movimentos pessimistas e otimistas, mas a verdade é que o ato de conhecer é um fenômeno estranho e enigmático e tráz também imensos problemas naquele que quer conhecer. Assim sendo, temos que concordar com Heráclito, há uma interdição: "conhecer o mundo é fazer a topografia de uma chama". 


\section{Considerações finais}

Busquei-me a mim mesmo (Heráclito, fragmento 101).

É fascinante ser provocado pelos ensinamentos budistas e pelas reflexões de Heráclito e perceber paralelos nas suas afirmações sobre os mistérios da existência; é interessante observar como colocam o mundo como algo que não pode ser objetivado, analisado cientificamente e controlado segundo uma vontade humana racional. O que podemos concluir é que vivemos em uma maré de ir e vir incontrolável, como diz Heidegger, em um processo de impermanência como diz o Budismo e de total inconstância e movimento como afirmava Heráclito. Talvez possamos também, ainda hoje, continuar reafirmando que no mundo das aparências e da multiplicidade, nas bolhas de realidade, no mundo da inconsciência humana nada é fixo e estabelecido e que ainda não temos como mantê-lo sob nosso controle. É unânime afirmar aqui também a ideia de que um jogo de opostos continua a marcar, até hoje, o drama do mundo e que assim sendo estamos jogados em um infindável combate de claro-escuro, fora - dentro, visível - invisível, idêntico - não idêntico, demora- urgência, lonjura proximidade, recolhimento - agitação...

Platão também entendia esse mundo no qual vivemos como um mundo das multiplicidades, das contradições e dos opostos, mas talvez o que o diferencie de Heráclito e de Buddha seja a promessa de uma saída, de um escape racional dessa caverna através de um olhar para fora, através de uma caminhada lógica, préestabelecida, com normas e regras exatas e claras em direção a um conhecimento absoluto da realidade. Para Platão era possível conhecer através da razão e o homem ocidental parece ter acreditado e fundamentado todo o seu pensamento nessa crença platônica. Talvez tenhamos esquecido, com Platão, a interdição apontada pelos antigos. Acreditamos ter saído da caverna e ter conhecido a verdadeira natureza da realidade, achamos que havíamos decifrado o mistério e não olhamos mais para trás, ou melhor, não olhamos mais para dentro de nós mesmos, não buscamos mais a nós mesmos, como havia aconselhado Heráclito. Não ouvimos Heráclito, seguimos Platão. Achamos que já estávamos encaminhados, que bastava olhar para a Luz, era só olhar para fora, estava 
tudo claro, visível e estável, no mundo exterior, no âmbito das Ideias. Achamos que já tínhamos entendido tudo e que já podíamos seguir na direção mais do que certa e clara da "Ideia", da "Verdade".

Puro engano, diria o pré-socrático e os ensinamentos budistas.

Mas, nem tudo está perdido, ainda podemos fazer a meia volta e tomar outro caminho. Há a arte para Heidegger, o movimento que tira o véu, que desvela a verdade e proporciona a abertura originária do ser do ente. Há a arte que nos leva de volta à raiz, ao interior, ao fundamento do ser, ao recolhimento silencioso e oculto da terra. Podemos readmitir a ocultação e a interdição. Nem tudo está perdido, há a compreensão da mudança, a compreensão heraclítica de que é na mudança que as coisas encontram o seu repouso, que é na compreensão do combate harmonioso entre os opostos que talvez possamos amenizar o sofrimento humano, que é na compreensão da existência de uma harmonia entre as tensões contrárias, como a do arco e da lira, que talvez possamos compreender que permanecer significa mover-se. A compreensão de que há contradições em todo lugar em todos os âmbitos e de que não há nada de errado nisso. A compreensão de que somente através de uma busca interior, de uma meditação silenciosa e constante é que poderemos superar as contradições e alcançar a sabedoria primordial.

Heráclito, conta Diógenes Laércio, rompeu com Éfeso e retraiu-se da cidade, tornou-se misantropo e buscou asilo na zona sagrada do templo de Ártemis. Na solidão e no silêncio de sua ermida, passou em revista seu passado, seu agir e pensar. Meditou pacientemente sobre os problemas que, havia longos decênios, o preocupavam e sobre as soluções que descobrira (Berge, p.52).

Siddharta prosseguiu solitário até a árvore bodhi, a algumas milhas ao sul da vila de Gaya. Tomando assento sob a árvore, fez votos de não se levantar até que tivesse atingido a completa e perfeita Iluminação... Compreendeu as operações internas do samsara, o ciclo do nascimento e da morte; compreendeu as vidas passadas de todos os seres e observou o karma em operação. Compreendeu os padrões de sofrimento, o emaranhado de suas causas e condições e a maneira de trazê-las a um fim. Com a vinda da aurora, atravessou os mais sutis obstáculos ao conhecimento e transcendeu o 
sofrimento para tornar-se um Buddha completamente desperto (Caminhos para a Iluminação, p.33-34).

Na medida em que os ensinamentos de Buddha são introduzidos na civilização ocidental podemos hoje testemunhar a conjunção do conhecimento antigo e do moderno, o encontro do Leste com o Oeste; perceber as semelhanças nas buscas desesperadas dos antigos e dos modernos em compreender os mistérios da natureza humana. As pessoas do Ocidente começam a perceber que a complexidade das dificuldades que enfrentamos hoje, como indivíduos e como membros de uma sociedade ainda mais complexa e globalizada, não poderá ser solucionada com um conhecimento puramente racional. Parece haver cada dia mais a compreensão dos limites desse conhecimento lógico e da necessidade de uma nova abordagem que nos leve a uma visão mais iluminada e ao fim da dor e do sofrimento. 


\section{Referências Bibliográficas}

1. BERGE, Damião, $O$ Logos Heraclítico, Introdução ao estudo dos fragmentos, Instituto Nacional do Livro, Ministério da Educação e Cultura, Rio de Janeiro, 1969.

2. CAMINHOS PARA A ILUMINAÇÃO, Estudos Budistas no Instituto Nyingma, Série: Educação, Instituto Nyingma do Rio de Janeiro, Editora Dharma do Brasil, Rio de Janeiro, São Paulo, 2004.

3. KAHN, Charles H., A Arte e o Pensamento de Heráclito, uma edição dos fragmentos com tradução e comentários, tradução de Élcio de Gusmão Verçosa Filho, São Paulo: Paulos, (Coleção Philosophica), 2009.

4. KIRK G.S., RAVEN J.E., SCHOFIELD M., Os Filósofos Pré-Socráticos, História Crítica com Seleção de Textos, Fundação Calouste Gulbenkian, Serviço de Educação e Bolsas, Tradução de Carlos Alberto Louro Fonseca 7ª Edição, 2010.

5. NAKAMURA, Hajime, A Comparative History of Ideas, Motilal Banarsidass Publishers Private limited, New Delhi, First Indian Edition, 1992.

6. SOGYAL RINPOCHE, O Livro Tibetano do Viver e do Morrer, tradução Luiz Carlos Lisboa, Editora Talento, Editora Palas Athena, São Paulo, 1999.

7. TULKU, Tarthang, A Expansão da Mente, Tradução Manoel Vidal, Revisão técnica, Instituto Nyingma do Brasil, Editora Cultrix, São Paulo, 1978.

8. TULKU, Tarthang, A Liberdade Oculta da Mente, Psicologia e Meditação, Tradução do original em inglês e primeira revisão do Grupo de Tradução do Instituto Nyingma do Rio de Janeiro, Dharma Publishing, Rio de Janeiro, 2007.

9. THE SUTTA-NIPATA, translated by H. Saddhatissa, Routledge Curzon, Taylor \& Francis Group, London and New York, first published in 1985, Transferred to Digital Printing 2003.

10. THE DHAMMAPADA, Translated from the Pali with an Essay on Buddha and the Occident, by Irving Babbitt, A New Directions Paperbook, sixteenth printing, originally published by Oxford University Press, New York, 1965. 